\title{
Islet amyloid deposits preferentially Endocrine in the highly functional and most blood-perfused islets
}

\author{
Sara Ullsten', Sara Bohman', Marie E Oskarsson', K Peter R Nilsson², \\ Gunilla T Westermark ${ }^{1}$ and Per-Ola Carlsson ${ }^{1,3}$ \\ ${ }^{1}$ Department of Medical Cell Biology, Uppsala University, Uppsala, Sweden \\ 2Department of Chemistry, Linköping University, Linköping, Sweden \\ ${ }^{3}$ Department of Medical Sciences, Uppsala University, Uppsala, Sweden
}

\author{
Correspondence \\ should be addressed \\ to S Ullsten \\ Email \\ sara.ullsten@mcb.uu.se
}

\begin{abstract}
Islet amyloid and beta cell death in type 2 diabetes are heterogeneous events, where some islets are affected early in the disease process, whereas others remain visibly unaffected. This study investigated the possibility that inter-islet functional and vascular differences may explain the propensity for amyloid accumulation in certain islets. Highly blood-perfused islets were identified by microspheres in human islet amyloid polypeptide expressing mice fed a high-fat diet for three or 10 months. These highly blood-perfused islets had better glucose-stimulated insulin secretion capacity than other islets and developed more amyloid deposits after 10 months of high-fat diet. Similarly, human islets with a superior release capacity formed more amyloid in high glucose culture than islets with a lower release capacity. The amyloid formation in mouse islets was associated with a higher amount of prohormone convertase 1/3 and with a decreased expression of its inhibitor proSAAS when compared to islets with less amyloid. In contrast, levels of prohormone convertase 2 and expression of its inhibitor neuroendocrine protein 7B2 were unaltered. A misbalance in prohormone convertase levels may interrupt the normal processing of islet amyloid polypeptide and induce amyloid formation. Preferential amyloid load in the most blood-perfused and functional islets may accelerate the progression of type 2 diabetes.
\end{abstract}

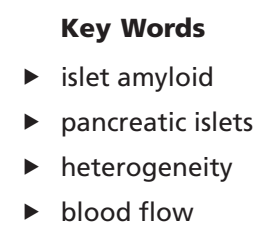

Endocrine Connections (2017) 6, 458-468

\section{Introduction}

Wide heterogeneities among and within pancreatic islets have previously been identified. Beta cells vary in size, granularity, proliferation, functionality and maturation $(1,2,3)$. Some subsets of beta cells are more adaptable during pregnancy and metabolic challenges, and beta cells have also shown age-dependent variations $(4,5,6)$. On an inter-islet level, we have previously described two subpopulations of islets distinguished by their differences in blood supply; one low blood-perfused, low-oxygenated population with dormant metabolic activity (7), and another population with a high blood supply exhibiting superior functionality and beta cell proliferation indexes (8). Noteworthy, the latter population of high-functioning islets exhibited an increased sensitivity to hypoxia and cytokines leading to reduced survival upon stress (9).

Also, islet lesions have been shown to be of a heterogeneous nature and the beta cell loss in type 2 diabetes (T2D) is not consistent between islets or between different parts of the pancreas (10). Islet amyloid, a clinical finding seen in approximately 90\% of T2D patients, certainly affects islets in this irregular pattern; some islets may contain large amounts of amyloid in contrast http://www.endocrineconnections.org
DOI: 10.1530/EC-17-0148 (c) 2017 The authors Published by Bioscientifica Ltd

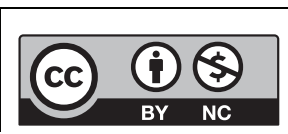

This work is licensed under a Creative Commons Attribution-NonCommercial 4.0 International License. 
to adjacent islets that appear unaffected (11). Aggregates of islet amyloid polypeptide (IAPP) are cytotoxic and associated with beta cell death both in T2D (12) and in islets after their transplantation $(13,14,15)$. Many biological and chemical factors have been described to affect the aggregation of IAPP. In T2D, a major trigger for amyloid formation is the increased IAPP production and secretion. In vitro studies show that IAPP is co-secreted with insulin, and that an enhanced secretion may induce amyloid. In cultured islets, amyloid deposit formation is glucose dose dependent and high glucose concentrations stimulate the process (16). Other insulin and IAPP secretagogues agents like extendin-4, potassium chloride, leucine, tolbutamide, glutamine or alpha-ketoisocaproic acid also induce amyloid in cultured islets $(17,18)$. On the other hand, substances that decrease IAPP secretion like diazoxide or somatostatin limited amyloid deposit formation (18). In vivo, in transgenic mice overexpressing human IAPP (hIAPP), the overexpression is not enough for amyloid to develop; amyloid will only form if the animals are predisposed with a genetic or environmental trigger like genetic obesity and hypolipidemia (ob/ob), high-fat diet (HFD) or administration of glucocorticoids $(19,20,21)$. IAPP itself has a significant role in the peptides misfolding and aggregation. ProIAPP is more prone to form aggregations than mature IAPP and a hypersecretion of proIAPP due to aberrant processing by the prohormones $\mathrm{PC} 1 / 3$ and $\mathrm{PC} 2$ may result in misfolding $(22,23)$. Also, ER stress induced by chronic hyperglycemia or compensatory insulin production, and glycosaminoglycans like heparan sulfates, have been suggested as important factors (23). Heparan sulfate is highly expressed in islets and important for islet function (24), but has also been identified in amyloid plaques in T2D (25). The glycosaminoglycan is located at the basement membrane of the beta cell and can interact with the N-terminal region of human proIAPP/IAPP, which will stabilize the peptide and thus form a nidus for amyloidogenesis $(26,27)$.

In our previous studies of highly blood-perfused islets, we have showed that these islets, besides an increased capacity for glucose-stimulated insulin release, also had substantial differences in gene expression when compared to other islets, including a higher IAPP gene expression (8). To investigate amyloid content and fibrillogenesis in highly functional islets we used in the present study, a mouse model expressing hIAPP, as well as single human islets cultured in high glucose. We hypothesized that highly functional islets would be more predisposed for amyloid formation.

\section{Materials and methods}

\section{Experimental animals}

Male mice deficient in mouse IAPP (mIAPP), but expressing hIAPP $\left(\right.$ mIAPP $^{-/-}$, hIAPP $^{+/+}$) (28) had free access to water and standard chow. Throughout the experimental studies, the animals additionally had free access to lard (HFD) (28). Experiments were performed after short-term (3-months) or long-term (10-months) HFD (28). All experimental procedures were approved by the Ethical Committee at Uppsala University.

\section{Detection of highly blood-perfused islets}

The animals were anesthetized with i.p. injections of avertin (Sigma-Aldrich) and placed on a heating pad to maintain body temperature. Polyethylene catheters were inserted into the ascending aorta for continuous blood pressure measurement and subsequent microsphere injection and into the left femoral artery for blood sampling. After the surgical procedure, the animals were allowed to stabilize their blood pressure for $10 \mathrm{~min}$ before injection of black $(10 \mu \mathrm{m}, \mathrm{E}-\mathrm{Z}$ Trac Ultraspheres; IMT, Stason Labs., Irvine, CA, USA) or fluorescent microspheres $(10 \mu \mathrm{m}$, FluoSpheres Polystyrene Microspheres; Molecular Probes), into the ascending aorta. A reference blood sample was obtained by free flow from the femoral artery. It was collected for $60 \mathrm{~s}$, with a start $5 \mathrm{~s}$ before microsphere injection, to enable quantitative determination of blood flow $(8,9)$. The pancreas was thereafter immediately retrieved for islet isolation or immunohistochemistry.

\section{Islet isolation}

Mouse islets were isolated by collagenase digestion, hand-picked and incubated in groups of 100 overnight at $37^{\circ} \mathrm{C}$ (air/ $\left.\mathrm{CO}_{2}, 95: 5\right)$ in $5 \mathrm{~mL}$ RPMI-1640 medium (SigmaAldrich) supplemented with $2 \mathrm{mmol} / \mathrm{L}$ L-glutamine, $11.1 \mathrm{mmol} / \mathrm{L}$ glucose, $10 \%(\mathrm{v} / \mathrm{v})$ fetal calf serum (FCS) and $0.1 \mathrm{mg} / \mathrm{mL}$ streptomycin (Roche Diagnostics Scandinavia) (29). The islets were thereafter dichotomously sorted in a fluorescence microscope. Microsphere-containing islets were size-matched to control islets without microspheres from the same mouse $(8,9)$.

\section{Amyloid evaluation in mouse islets}

Islets of animals fed 10-month HFD were following their isolation fixed in $10 \%(\mathrm{v} / \mathrm{v})$ buffered formalin and

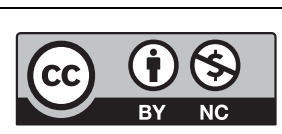

This work is licensed under a Creative Commons Attribution-NonCommercial 4.0 International License. 
embedded in paraffin. Consecutive sections $(5 \mu \mathrm{m})$ were stained for amyloid with Congo red (Sigma-Aldrich) (30). Sections of size-matched islets with and without microspheres were photographed in a fluorescence microscope and the amyloid area was calculated as percentage of the total area of the islet. Image analysis was performed with Image (NIH).

\section{Location of microsphere-containing islets}

From 3-month HFD microsphere-injected animals, the pancreas was oriented with a suture in the tail part, immobilized and consecutively sectioned (10 $\mu \mathrm{m})$ perpendicularly to the longitudinal axis of the pancreas. Microsphere-containing islets were identified in a light microscope after hematoxylin-eosin staining. Whole section scanning of whole pancreases was performed by Aperio Scanscope AT (Leica Biosystems, Nussloch, Germany). The distance from the center of each microsphere- or non-microsphere-containing islet to the pancreatic center, defined as the origo of an image fitting the whole pancreatic section, was calculated with Aperio ImageScope software (Leica Microsystems, Wetzlar, Germany).

\section{Mouse islet glucose-stimulated hormone release}

Islets isolated from hIAPP animals fed 3-month HFD were sorted based on their microsphere content or not and incubated at low $(1.67 \mathrm{mmol} / \mathrm{L})$ and high glucose $(16.7 \mathrm{mmol} / \mathrm{L})$ concentrations for $60 \mathrm{~min}$, respectively (31). The supernatants from both incubations were collected and analyzed for mouse insulin and human IAPP with ELISA (Mercodia, Uppsala, Sweden and EZHA52K, Merck Millipore, respectively). Stimulation index was calculated accordingly (insulin release in high glucose)/ (insulin release in low glucose). The islets were harvested to measure total hormone content and to ensure equal islet size in the groups by DNA measurement (Quant-iT PicoGreen dsDNAassay kit, Molecular Probes).

\section{Mouse islet gene expression}

RNA was extracted from isolated islets of animals fed 3-month HFD by the use of RNAeasy Plus Mini Kit (Qiagen) followed by first-strand cDNA synthesis by SuperScript III First-Strand Synthesis SuperMix (Invitrogen). qPCR was performed using a Light Cycler 480t (Roche Diagnostics) and Light Cycler FastStart DNA Master PLUS SYBR Green I (c) 2017 The authors

http://www.endocrineconnections.org DOI: 10.1530/EC-17-0148 kit (Roche Diagnostics). Gene expression was normalized to the reference gene Tata-box-binding protein (TBP). For primer information, see Supplementary Table 1 (see section on supplementary data given at the end of this article).

\section{Prohormone convertase (PC) protein levels in mouse islets}

Pancreas sections obtained from animals fed 3-month HFD were incubated with monoclonal mouse PC1/3 and PC2 antibodies (22) together with an insulin antibody (Fitzgerald, Acton, MA, USA). Heat-induced antigen retrieval $(20 \mathrm{~min})$ in $0.01 \mathrm{~mol} / \mathrm{L}$ sodium citrate was performed for PC2 staining only. Fluorescent anti-mouse 488 (1:200, Jackson ImmunoResearch Laboratories) and anti-guinea pig 555 (1:1000 Molecular Probes) were used for primary antibody detection. To quantify PC protein levels on sections, images were acquired using a confocal laser scanner microscope (Zeiss LSM780) and analyzed with ImageJ (NIH).

\section{Heparan sulfate quantification in mouse islets}

In pancreases obtained from 3-month HFD animals, heparan sulfate (HS) glycosaminoglycans were identified with Alcian blue CEC staining (0.65 mol/ $\mathrm{L} \mathrm{MgCl}_{2}, \mathrm{pH} 5.8$, Sigma-Aldrich) (32). Reciprocal staining intensity was analyzed with ImageJ (NIH).

\section{Human islets}

Human islets from brain-dead, heart-beating donors, provided by the Nordic Network for Clinical Islet Transplantation (22-42 islets/donor, for donor data, Table 1), were individually cultured in CMRL 1066 supplemented with $10 \%$ (v/v) FCS, 2 mmol/L L-glutamine, $0.1 \mathrm{mg} / \mathrm{mL}$ streptomycin (Roche Diagnostics Scandinavia) and 5.5 or $20 \mathrm{mmol} / \mathrm{L}$ glucose. Experiments involving human islets were approved by the regional ethical board in Uppsala, Sweden.

Table 1 Human islet donor characteristics.

\begin{tabular}{|c|c|c|c|c|}
\hline Donor & Sex & Age & BMI $\left(\mathrm{kg} / \mathrm{m}^{2}\right)$ & $\mathrm{HbA} 1 \mathrm{C} \%(\mathrm{mmol} / \mathrm{mol})$ \\
\hline Donor 1 & $\mathrm{M}$ & 38 & 41.7 & $5.2(33)$ \\
\hline Donor 2 & $\mathrm{~F}$ & 59 & 22.0 & $5.8(40)$ \\
\hline Donor 3 & $\mathrm{~F}$ & 73 & 22.3 & $5.8(40)$ \\
\hline Donor 4 & $\mathrm{~F}$ & 69 & 23.9 & $6.5(47)$ \\
\hline
\end{tabular}

Data received from the Nordic Network for Clinical Islet Transplantation. BMI, body mass index; HbA1C, glycated hemoglobin. 


\section{Human islet insulin release}

Prior to high glucose culture (day 0), insulin release experiments were performed on individual islets to evaluate their functionality. Islets were pre-incubated in $1.67 \mathrm{mmol} / \mathrm{L}$ glucose for $30 \mathrm{~min}$. Glucose-stimulated insulin release of single islets was then determined by incubation of them in 1.67 and $16.7 \mathrm{mmol} / \mathrm{L}$ glucose for $60 \mathrm{~min}$, respectively. The supernatants were analyzed by an Ultrasensitive Insulin ELISA (Mercodia). Stimulation index was calculated accordingly: (insulin release in high glucose)/(insulin release in low glucose).

\section{Islet amyloid quantification in human islets}

Human islets were cultured individually ( 30 islets/ donor) in $20 \mathrm{mmol} / \mathrm{L}$ glucose for 18 days to stimulate IAPP secretion and subsequent amyloid formation (27). To visualize islet amyloid, the live islets were incubated with the amyloid-specific oligothiophene p-FTAA (30 $\mu \mathrm{mol} / \mathrm{L})$ $(33,34)$ for $60 \mathrm{~min}$ and thereafter imaged in a fluorescence microscope at $488 \mathrm{~nm}$ excitation. Image analysis was performed with Image $(\mathrm{NIH})$.

\section{Statistical analysis}

All values are given as means \pm s.E.M. Parametrical data were analyzed by unpaired or paired Student's $t$ test, and the distribution of amyloid between islets were calculated by a chi-square test. Gene expression analysis was performed on the $\Delta \mathrm{CT}$ values for each gene. $P<0.05$ was considered significant.

\section{Results}

\section{Animal characteristics and blood flow}

$\mathrm{hIAPP}^{+/+} \mathrm{mIAPP}^{-/-}$mice increased in weight during HFD treatment and weighed $33 \pm 1 \mathrm{~g}(n=23)$ and $44 \pm 1 \mathrm{~g}(n=7)$ after 3 and 10 months on HFD, respectively. The animals were all normoglycemic $(6.7 \pm 0.2 \mathrm{mmol} / \mathrm{L} ; n=30)$. In the experiments, each microsphere corresponded to a blood flow of $\geq 0.21 \pm 0.02 \mu \mathrm{L} / \mathrm{min}(n=30)$.

\section{Amyloid in mouse islets}

After 10-month HFD, amyloid deposits ( $\geq 0.1 \%$ islet area) were more frequent in islets with microspheres than in those without microspheres ( $n=7$, Fig. 1A, B and C).
The amyloid deposits were also twice as extensive (percentage of islet area) in the highly blood-perfused islets when compared to size-matched islets without microspheres ( $n=7$, Fig. 1D).

\section{Location of highly blood-perfused islets}

Islets with microspheres were found throughout the pancreas. Islets with and without microspheres were similarly distributed in the central and peripheral parts of the gland $(1.39 \pm 0.18$ vs $1.34 \pm 0.17 \mathrm{~mm}$ to center, respectively, $n=4)$.

\section{Glucose-stimulated hormone release}

No difference in islet size was measured between the investigated islets with and without microspheres (81.2 \pm 13.5 vs $70.2 \pm 12.1 \mathrm{ng}$ DNA/islet, respectively, $n=6$ animals). There was neither any difference in insulin or IAPP content between the two groups of islets ( $6218 \pm 1136$ vs $6891 \pm 1817 \mathrm{fmol}$ insulin/islet and $377 \pm 80$ vs $375 \pm 84 \mathrm{fmol}$ IAPP/islet in islets with- and without microspheres, respectively, $n=6$ ). There was no difference between the two groups of islets in insulin release at a low glucose concentration $(1.67 \mathrm{mmol} / \mathrm{L})$, but in response to a high glucose concentration $(16.7 \mathrm{mmol} / \mathrm{L})$, the microspherecontaining islets secreted $\sim 30 \%$ more insulin than the size-matched islets without microspheres (Fig. 1E). When calculating the glucose stimulation index (ratio of insulin release in high and low glucose concentration), islets with microspheres had a $44 \%$ higher ratio $(n=6$, Fig. $1 F)$. No difference was however seen between the groups in IAPP release at either a low or a high glucose concentration (Fig. 1G). Islets with microspheres therefore had a ratio of released IAPP/insulin in response to glucose that was $\sim 30 \%$ lower than other islets (Fig. 1H).

\section{Amyloid in human islets}

Little or no amyloid ( $<1 \%$ of islet area) was found at day 0 in the islets obtained from four different donors. After functional test of single islets, the islets were cultured individually for 18 days in high glucose to allow amyloid formation. At day 18, the islets had developed amyloid covering $\sim 4 \%$ (range $0-30 \%$ ) of the islet area. The islets were thereafter divided into two groups; islets with little or no $(<1 \%$ of islet area) amyloid $(n=58)$ and islets with amyloid ( $>1 \%$ of islet area) $(n=59)$. The group of islets that formed amyloid after 18 days of high glucose culture was

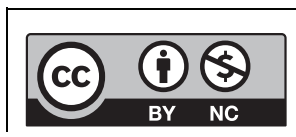

This work is licensed under a Creative Commons Attribution-NonCommercial 4.0 International License. 

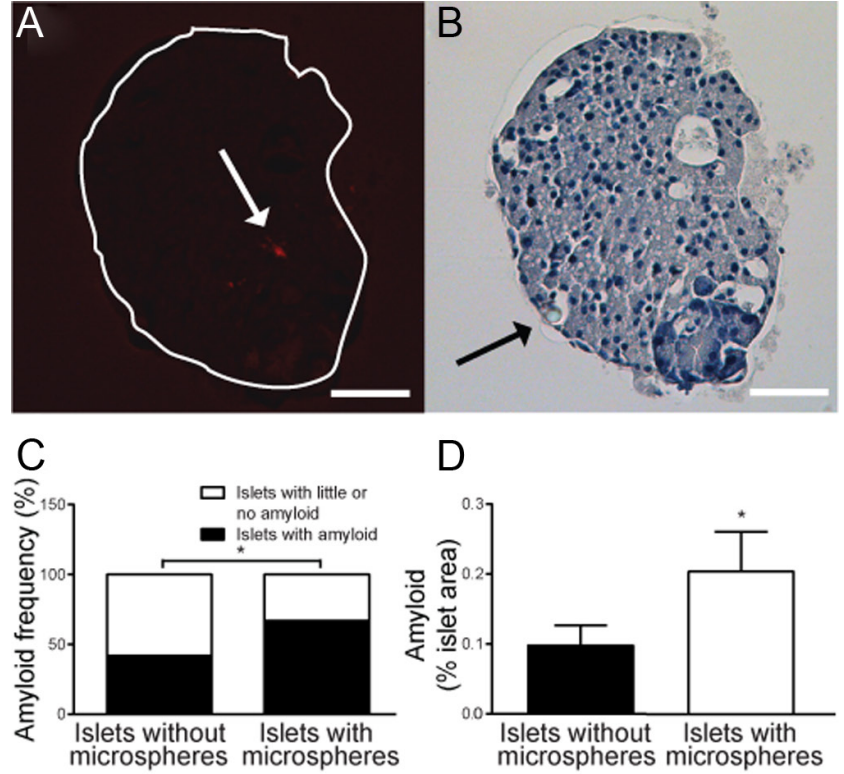

D

E

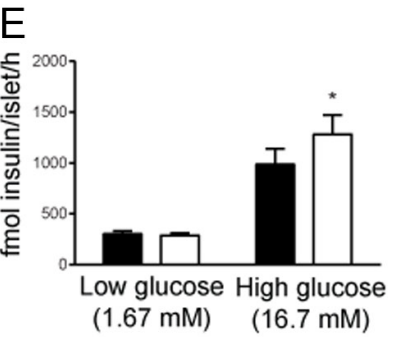

G
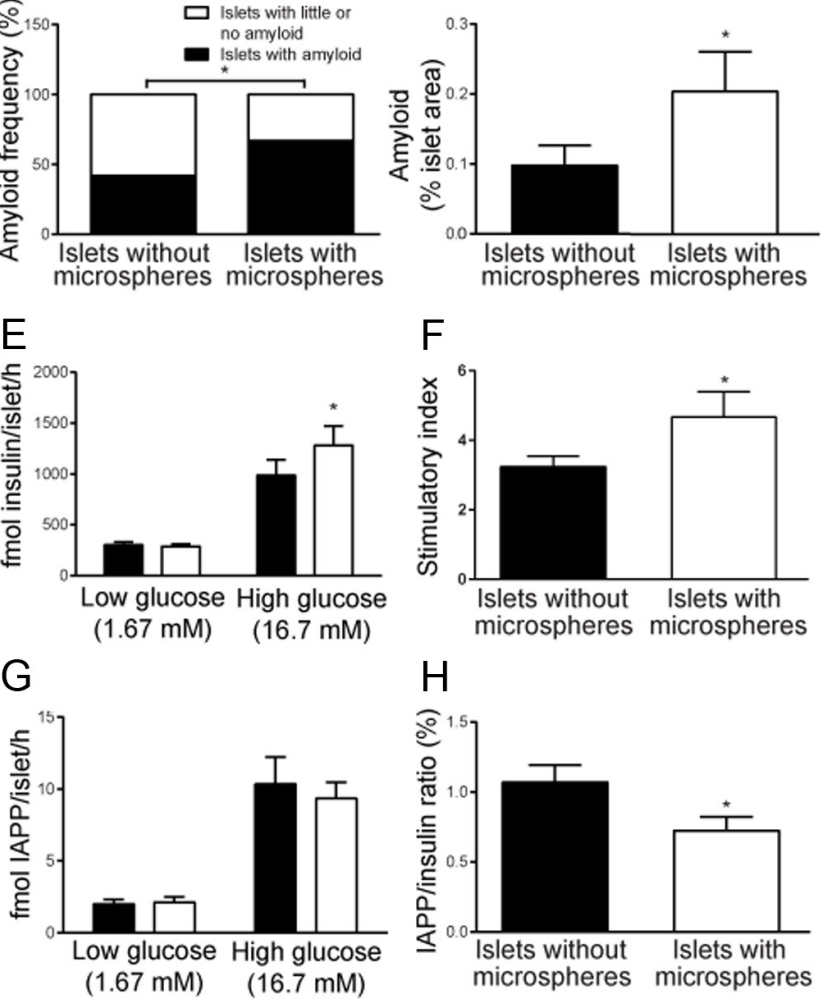

$\mathrm{F}$

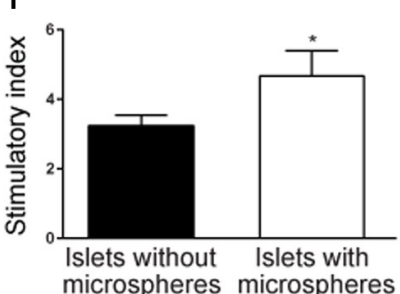

$\mathrm{H}$

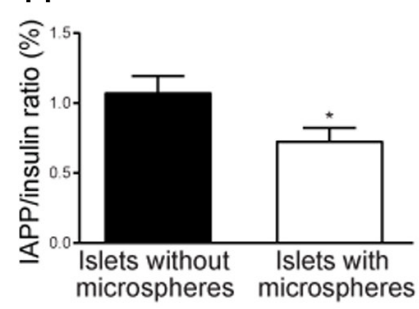

Figure 1

Function and amyloid content in high-fat diet (HFD)- fed mice expressing human islet amyloid polypeptide (hIAPP). Fluorescence (A) and brightfield (B) images of Congo red and hematoxylin-stained islet from mouse after 10-month HFD with amyloid deposit (white arrow) and microsphere (black arrow). Scale bar $50 \mu \mathrm{m}$. (C) In the group of islets with microspheres, the frequency of islets containing amyloid ( $\geq 0.1 \%$ islet area) was higher (closed bar segment) when compared to islets without microspheres. (D) The amyloid deposits were twice as extensive in highly blood-perfused islets (marked with microspheres) (open bar) when compared to size-matched islets without microspheres (closed bar). (E) After feeding of mice for three months with HFD, the glucose-stimulated insulin release was higher from islets with microspheres (open bar) vs control islets (closed bar). (F) Calculated glucose stimulation index was higher in islets with microspheres (open bar) vs control islets (closed bar). (G) There was no difference between control islets (closed bar) and microspherecontaining islets (open bar) with regard to IAPP release in either low $(1.67 \mathrm{mmol} / \mathrm{L})$ or high $(16.7 \mathrm{mmol} / \mathrm{L})$ glucose concentrations. $(\mathrm{H})$ The ratio of released IAPP to insulin was lower in islets with microspheres when compared to control islets without microspheres. Values are given as means \pm S.E.M. for 6 animals. ${ }^{*} P<0.05$ vs islets with microspheres. found to have an $~ 50 \%$ better glucose-stimulated insulin release when measured prior to the high glucose culture (Fig. 2A). This was observed in islets from all four donors (Fig. 2B). In contrast, there was no visible amyloid in any of the islets before high glucose culture (day 0) (Fig. 2C, D, E, F, G, H, I and J).

\section{ProlAPP processing enzymes}

No difference in gene expression of the two prohormone convertases PC1/3 and PC2 ( $n=6$, Fig. $3 \mathrm{~A}$ and B) and the processing enzyme Carboxypeptidase E (CPE) (fold change $0.73 \pm 0.20$ in islets with microspheres, $n=5$ ) could be observed between islets with or without microspheres. However, the expression of the neuroendocrine peptide precursor proSAAS was $\sim 50 \%$ lower in the microspherecontaining islets $(n=5$, Fig. 3C). 7B2, another neuroendocrine protein, did not differ between the two groups ( $n=6$, Fig. 3D). PC1/3 immunofluorescence co-localized with insulin staining and was $\sim 17 \%$ higher in islets with microspheres ( $n=4$, Fig. $3 \mathrm{E}, \mathrm{G}, \mathrm{H}, \mathrm{I}, \mathrm{J}, \mathrm{K}$ and $\mathrm{L})$. In contrast, the intensity of PC2 staining in insulinpositive cells did not differ between the islets with and without microspheres ( $n=4$, Fig. $3 \mathrm{~F}, \mathrm{M}, \mathrm{N}, \mathrm{O}, \mathrm{P}, \mathrm{Q}$ and $\mathrm{R}$ ).

\section{Highly sulfated glycosaminoglycans}

The intensity of HS staining did not differ between the islets with or without microspheres $(n=4$, reciprocal intensity $136.6 \pm 3.1$ vs $131.2 \pm 6.2 \mathrm{AU}$, respectively).

\section{IAPP-degrading enzymes}

A higher gene expression of the two matrix metalloproteinases MMP2 and MMP9 was observed in the islets with microspheres ( $n=5-6$, Fig. 4 A and B). No differences could be detected in the expression of the inhibitors tissue inhibitor of matrix metalloproteinases (TIMP) 1-3 between islet with or without microspheres ( $n=6$, Fig. 4C, D and E). There was neither any difference in the expression of insulin-degrading enzyme (IDE) ( $n=6$, fold change $1.54 \pm 0.51$ in islets with microspheres) and neprilysin $(n=4$, fold change $1.22 \pm 0.67$ in islets with microspheres).

\section{ER stress induced gene expression}

Gene expression of C/EBP-homologous protein (CHOP) ( $n=5$, fold change $1.21 \pm 0.37$ in islets with microspheres)

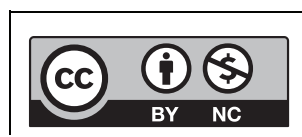

This work is licensed under a Creative Commons Attribution-NonCommercial 4.0 International License. 


\section{A}

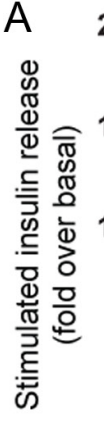

B

B

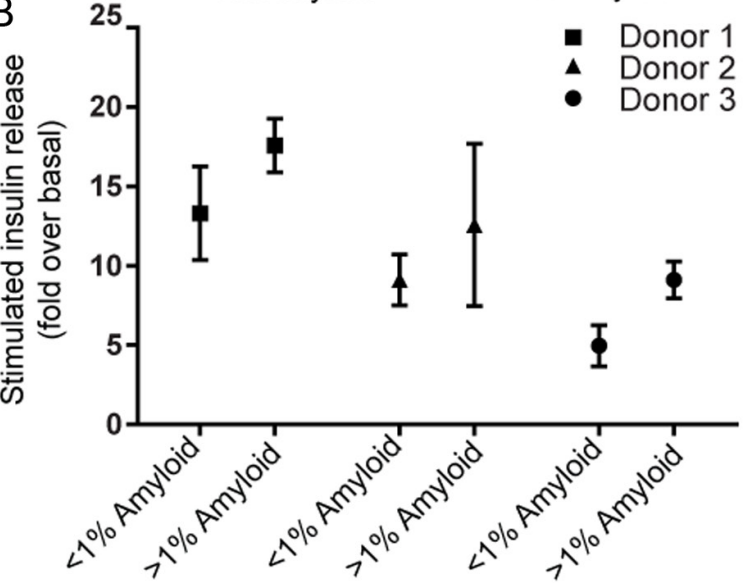

Islet with amyloid after 18 days

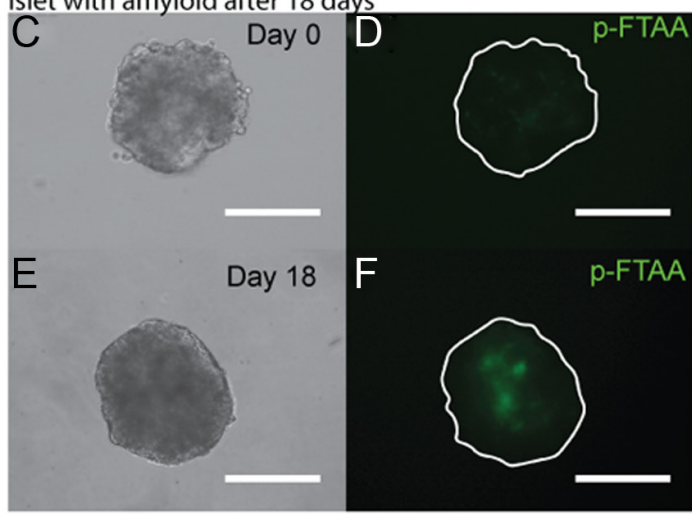

Islet with little or no amyloid after 18 days

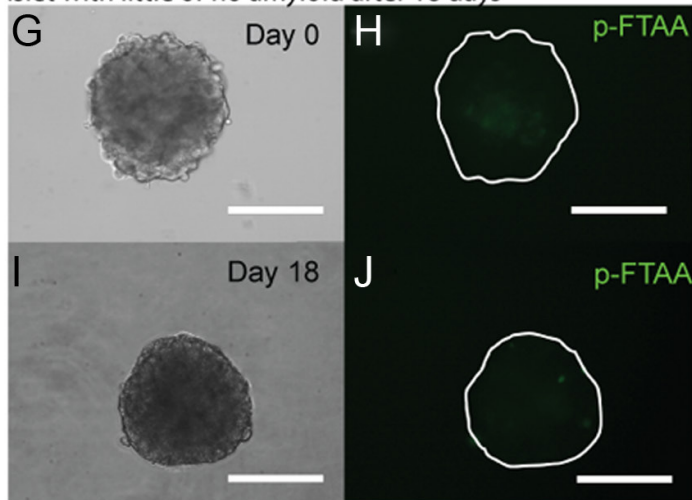

Figure 2

Glucose-stimulated insulin release and subsequent high glucose induced amyloid formation in human islets. (A) Human islets with amyloid formed after 18 days of high glucose culture had better glucose-stimulated insulin release prior to culture. (B) Similar findings were observed in islets from four different donors. Representative images of islet developing amyloid after high glucose culture at day 0 (C and D) and day 18 (E and F) and islet without amyloid after high glucose culture at day 0 ( G and $\mathrm{H}$ ) and day 18 (I and J), scale bar $100 \mu \mathrm{m}$. Values are given as means \pm S.E.M. for islets from four different donors and $\sim 120$ islets were investigated in total. ${ }^{*} P<0.05$ vs islets with less than $1 \%$ amyloid after culture.

and immunoglobulin-binding protein $(\mathrm{BiP})(n=5$, fold change $1.21 \pm 0.62$ in islets with microspheres) did not differ between the islets with or without microspheres.

\section{Discussion}

The present study describes increased susceptibility for islet amyloid formation in a subpopulation of highly blood-perfused and functionally active islets of hIAPP mice. In addition, a subgroup of human islets with a better insulin release capacity developed more amyloid during high glucose exposure. Increased amyloid in the highly blood-perfused functionally active islets of hIAPP mice was associated with an imbalance in PC protein levels. This imbalance with the following incapacity of processing proIAPP to mature IAPP has previously been described to be of great importance for the development of amyloid deposits $(22,35)$.

$$
\begin{aligned}
& \text { http://www.endocrineconnections.org } \\
& \text { DOI: 10.1530/EC-17-0148 }
\end{aligned}
$$

Identification of highly blood-perfused, highly functional islets has previously been performed by the microsphere technique $(8,9,36,37)$. In order to be able to study the tendency for amyloid formation in these islets, we used mice expressing hIAPP due to the nonamyloidogenic nature of rodent IAPP (28). These mice lack mIAPP to avoid interference with amyloid fibril formation. Since amyloid formation does not develop spontaneously in the hIAPP mouse model, a trigger of e.g. HFD is needed (28). In order to investigate visible amyloid deposits, we used mice fed a diet high in fat for 10 months to allow sufficient time for the development of the deposits. Also, we tried to identify mechanisms preceding the fibrillation process, and for these experiments, we used animals that had been fed a HFD for three months.

After 10 months of HFD, amyloid was detected in islets from all animals. However, when comparing islets, we observed preferential amyloid development in the islets with a high blood perfusion as identified by

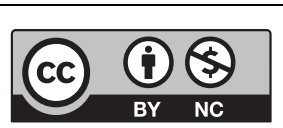

This work is licensed under a Creative Commons Attribution-NonCommercial 4.0 International License. 

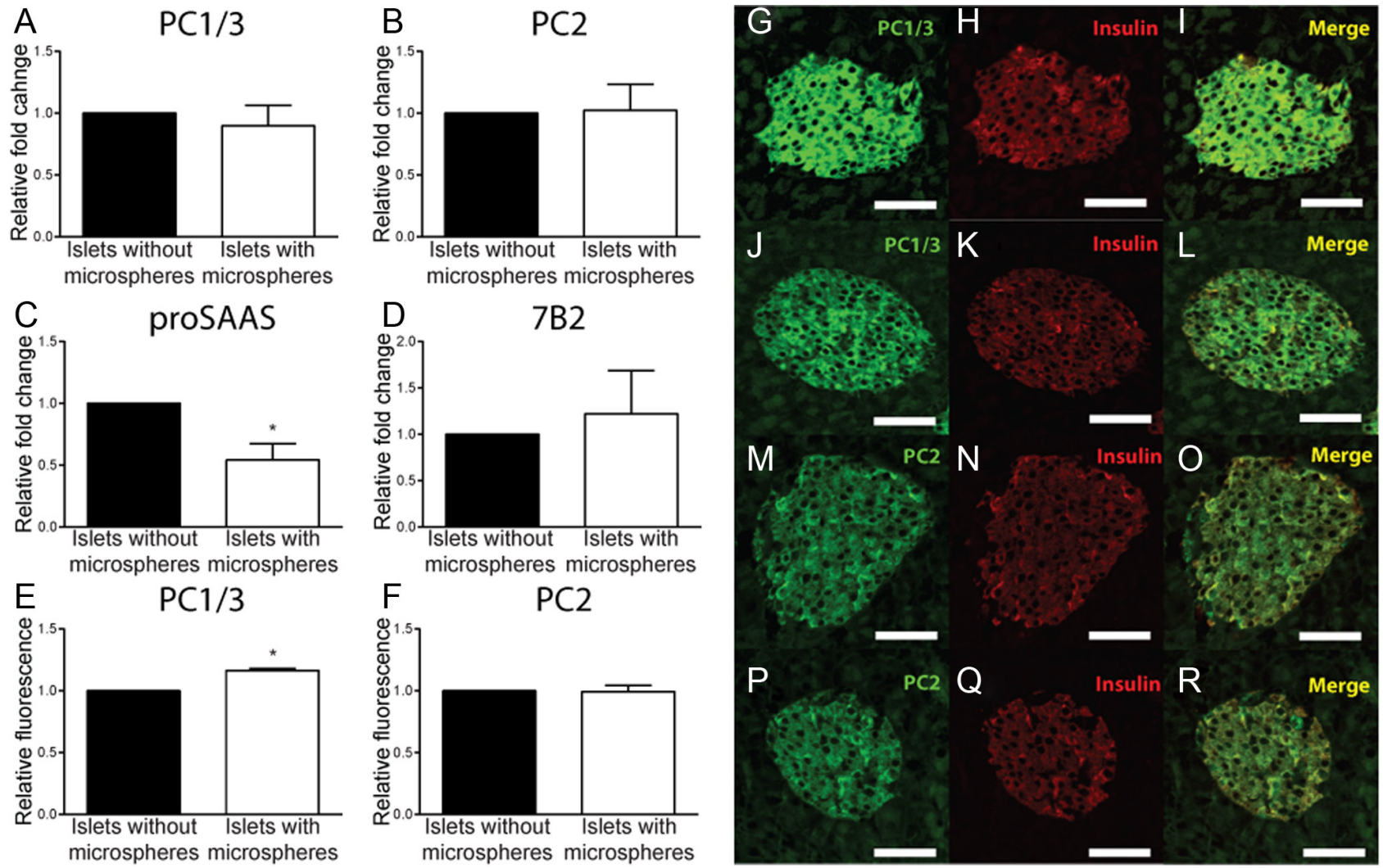

Figure 3

Prohormone convertase (PC) expression in islets from human IAPP-expressing mice fed for 3 months with high-fat diet (HFD). (A and B) The relative gene expression of $\mathrm{PC} 1 / 3$ and $\mathrm{PC} 2$ did not differ between the two groups of isolated islets with and without microspheres. (C) The expression of the inhibitor of PC1/3 activity, proSAAS, was decreased in islets with microspheres. (D) The expression of the corresponding inhibitor of PC2, 7B2, did not differ between the groups. PC protein levels evaluated as intensity of immunofluorescence of PC1/3 and PC2, showed higher amounts of PC1/3 in islets with microspheres ( $E, G, H$ and $I)$ when compared to control islets without microspheres $(E, J, K$ and $L)$. No difference in PC2 levels was seen between islets with microspheres ( $F, M$ and $N$ ) when compared to control islets without microspheres ( $, P, Q$ and $R$ ). Values are given as means \pm s.E.M. for $4-6$ animals. $\star P<0.05$ vs islets without microspheres.

microspheres. The amount of amyloid was also twice as extensive in these islets when compared to the group with lower blood perfusion.

Consistent with our previous study in rat (8), islets with high blood flow as identified by microspheres had an approximately 30\% higher insulin release than other islets in response to high glucose. However, when measuring IAPP secretion from the same islets, no difference could be seen between the two groups in either high or low glucose concentrations.

Since the glucose stimulation index, a measure of insulin secretory capacity, was particularly augmented in the highly blood-perfused mouse islets marked by microspheres, we decided to use this index for studies on human islets as the microsphere technique is restricted to experimental animal models and cannot be used to identify highly perfused human islets. The glucose stimulation index of each single human islet was evaluated at day 0 and the islets were subsequently cultured in high glucose medium for 18 days to induce IAPP secretion and amyloid formation (27). After 18 days of high glucose culture, extensive amyloid was seen in numerous islets (amyloid deposits range $0-30 \%$ of islet area). When the islets were divided into no or low $(<1 \%)$ or high $(>1 \%)$ amyloid content, islets that developed amyloid were found to have an approximately 50\% higher glucose stimulation index prior to the incubation irrespective of the donor.

To further investigate the mechanisms of amyloid formation in the highly blood-perfused, highly functional mouse islets, we studied the expression of the ER stress markers CHOP and BiP as ER stress has been described to be associated with amyloid formation in some (38), but not all studies (39). In this study, we did not see any indications of ER stress in the highly functional islets prone to develop amyloid. Another study has described a preferential location of human islets containing 

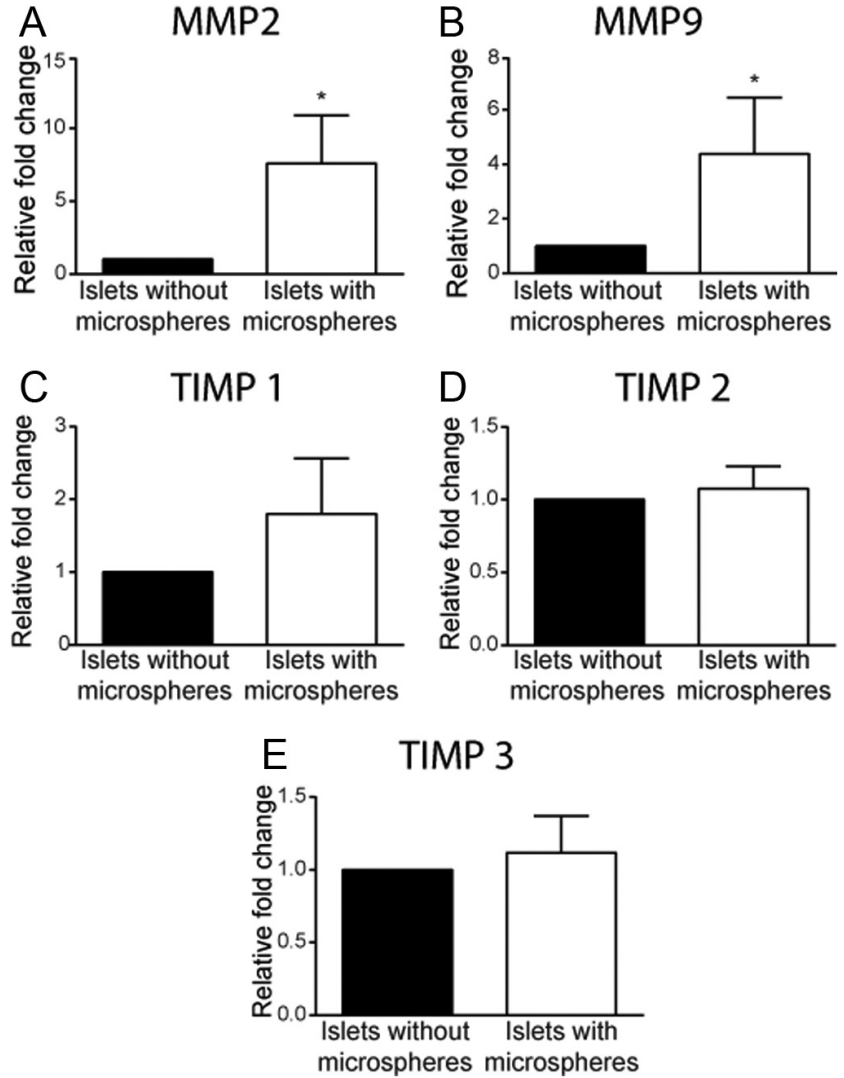

Figure 4

Gene expression analysis of matrix metalloproteinases (MMP) and their inhibitors in isolated islets of human IAPP expressing mice fed a high-fat $\operatorname{diet}(H F D)$ for 3 months. ( $A$ and $B$ ) The relative expression of the two metalloproteinases MMP2 and MMP9 was increased in islets with microspheres when compared to islets without microspheres. (C and E) The expression of the endogenous inhibitors TIMP1, TIMP2 and TIMP3 was similar between the two groups. Values are given as means \pm S.E.M. for $5-6$ animals. ${ }^{*} P<0.05$ vs islets without microspheres.

amyloid to the peripheral regions of the pancreas (40). We did, in our studies in mice, however, not find any regional differences of the position of microspherecontaining islets.

Processing deficiencies of proIAPP has been suggested to contribute to islet amyloid development in T2D $(41,42,43,44)$. An increased proinsulin-to-insulin ratio with a major proportion of partially processed des-31,32 proinsulin, a proinsulin intermediate partially processed by PC1/3 but not PC2, has also been identified in such patients (45). To investigate if proIAPP processing was altered in the highly blood-perfused islets, we performed gene expression analysis of $\mathrm{PC} 1 / 3$ and $\mathrm{PC} 2$, the two major processing enzymes of both IAPP and insulin precursor molecules. Since the regulation of the two prohormone convertases also has been shown to occur on a posttranscriptional level $(46,47)$, the levels of insulin, PC1/3 and PC2 were evaluated by immunohistochemistry as well. Although the intensity of insulin and PC2 did not differ, the PC1/3 intensity was increased with approximately $17 \%$ in islets containing microspheres. Although we were unable to investigate the activity of either PC1/3 or PC2, we also observed a decrease in the gene expression of the endogenous inhibitor of $\mathrm{PC} 1 / 3$, proSAAS, which couples to increased activity of PC1/3 (48). The corresponding inhibitor of PC2, 7B2, was unchanged.

PC1/3 appears to be more important for proinsulin processing than $\mathrm{PC} 2$, but both enzymes can process both the $\mathrm{COOH}$ - and $\mathrm{NH}_{2}$-terminal of proinsulin, although not as efficient as the two enzymes combined $(49,50)$. In contrast, proIAPP requires PC2 for processing at the $\mathrm{NH}_{2}$-terminus $(41,49)$. Interestingly, the proIAPP intermediate $\mathrm{N}$-IAPP with an unprocessed $\mathrm{NH}_{2}$-terminal has been suggested to be more amyloidogenic than mature IAPP (42) and has been identified in human amyloid deposits $(43,44)$. We were not able to measure $\mathrm{N}$-terminal intermediate proIAPP, but in diabetic mice transplanted with mouse islets expressing human proIAAP, lack of PC2 in the islet transplants caused rapid graft failure with recurrence of hyperglycemia (51). The authors concluded that an increased production of prefibrillar proIAPP aggregates is plausible to have contributed.

N-IAPP has been described to have an increased affinity to HS, which is located at the cellular surface. This is suggested to cause a locally increased concentration of the amyloidogenic processing intermediate, which may seed amyloid formation (52). As HS is important for islet function (24), we hypothesized that highly functional islets may have an increased amount of HS facilitating the observed increase in amyloid formation. We did, however, not find any differences in HS intensity between the two groups of islets. Nevertheless, an increased amount of high-affinity N-IAPP in the microsphere-containing islets may by itself seed the process.

Amyloid peptide $A \beta$ has been described to increase transcription of vascular MMP9 (53). This could be of importance for amyloid formation, since both MMP2 and MMP9 have shown the ability to degrade $A \beta$ to soluble and less fibrillogenic fragments (54). MMP9, but not MMP2, has also been described to degrade IAPP (55). We could detect an increase in both MMP2 and MMP9 expression in the microsphere-containing islets, a feature which might be a response to an increased fibrillation process in these islets. However, the effects of islet amyloid on MMP2 and MMP9 expression or the degradation capacity of the two matrix metalloproteinases have not been studied. An increased

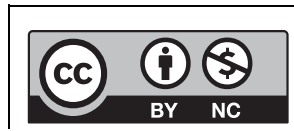

This work is licensed under a Creative Commons Attribution-NonCommercial 4.0 International License. 
expression may simply reflect the specific phenotype of the highly vascularized islets (56).

In conclusion, in the present study, we have found that the most functional islets of hIAPP mice and humans are more prone to develop amyloid than other islets. This may be explained by the observed imbalance between the two prohormone convertases PC1/3 and PC2 in these islets. As the subpopulation of islets that was affected by amyloid was the most functional one, the amyloid formation may result in unfavorable effects on longterm glucose homeostasis, which per se increases the metabolic demand and may speed up and worsen disease development.

\section{Supplementary data}

This is linked to the online version of the paper at http://dx.doi.org/10.1530/ EC-17-0148.

\section{Declaration of interest}

The authors declare that there is no conflict of interest that could be perceived as prejudicing the impartiality of the research reported.

\section{Funding}

The Swedish Research Council (55X-15043), the Swedish Child Diabetes Foundation, the Swedish Diabetes Foundation, Diabetes Wellness Sweden, the Novo Nordisk Foundation, and the strategic grant Excellence of Diabetes Research in Sweden (EXODIAB).

\section{Author contribution statement}

S U, S B, M O, P N, G T W and P O C designed the study and interpreted data. S U, S B and M O acquired and analyzed data. S U and P O C wrote the manuscript and S B, M O, P N and G T W revised the manuscript critically for intellectual content. All authors approved the final version of the paper.

\section{Acknowledgements}

Human islets were generously provided through the Nordic Network for Clinical Islet Transplantation. The skilled technical assistance of My Quach, Petra Franzén, Astrid Nordin, Birgitta Bodin and Lisbeth Sagulin is gratefully acknowledged.

\section{References}

1 Pipeleers D, Kiekens R, Ling Z, Wilikens A \& Schuit F. Physiologic relevance of heterogeneity in the pancreatic beta-cell population. Diabetologia 199437 (Supplement 2) S57-S64. (doi:10.1007/ BF00400827)

2 Bader E, Migliorini A, Gegg M, Moruzzi N, Gerdes J, Roscioni SS, Bakhti M, Brandl E, Irmler M, Beckers J, et al. Identification of proliferative and mature beta-cells in the islets of Langerhans. Nature 2016. 535 430-434. (doi:10.1038/nature18624)

3 Katsuta H, Aguayo-Mazzucato C, Katsuta R, Akashi T, Hollister-Lock J, Sharma AJ, Bonner-Weir S \& Weir GC. Subpopulations of GFPmarked mouse pancreatic beta-cells differ in size, granularity, and insulin secretion. Endocrinology 2012153 5180-5187. (doi:10.1210/ en.2012-1257)
4 Assefa Z, Lavens A, Steyaert C, Stange G, Martens GA, Ling Z, Hellemans K \& Pipeleers D. Glucose regulates rat beta cell number through age-dependent effects on beta cell survival and proliferation. PLoS ONE 20149 e85174. (doi:10.1371/journal.pone.0085174)

5 Schraenen A, Lemaire K, de Faudeur G, Hendrickx N, Granvik M, Van Lommel L, Mallet J, Vodjdani G, Gilon P, Binart N, et al. Placental lactogens induce serotonin biosynthesis in a subset of mouse beta cells during pregnancy. Diabetologia 201053 2589-2599. (doi:10.1007/s00125-010-1913-7)

6 Ellenbroek JH, Tons HA, de Graaf N, Loomans CJ, Engelse MA, Vrolijk H, Voshol PJ, Rabelink TJ, Carlotti F \& de Koning EJ. Topologically heterogeneous beta cell adaptation in response to high-fat diet in mice. PLoS ONE 20138 e56922. (doi:10.1371/journal.pone.0056922)

7 Olsson R \& Carlsson PO. A low-oxygenated subpopulation of pancreatic islets constitutes a functional reserve of endocrine cells. Diabetes 201160 2068-2075. (doi:10.2337/db09-0877)

8 Lau J, Svensson J, Grapensparr L, Johansson A \& Carlsson PO. Superior beta cell proliferation, function and gene expression in a subpopulation of rat islets identified by high blood perfusion. Diabetologia 201255 1390-1399. (doi:10.1007/s00125-012-2476-6)

9 Ullsten S, Lau J \& Carlsson PO. Vascular heterogeneity between native rat pancreatic islets is responsible for differences in survival and revascularisation post transplantation. Diabetologia 201558 132-139. (doi:10.1007/s00125-014-3385-7)

10 Wang X, Misawa R, Zielinski MC, Cowen P, Jo J, Periwal V, Ricordi C, Khan A, Szust J, Shen J, et al. Regional differences in islet distribution in the human pancreas - preferential beta-cell loss in the head region in patients with type 2 diabetes. PLoS ONE 20138 e67454. (doi:10.1371/journal.pone.0067454)

11 Westermark P, Andersson A \& Westermark GT. Islet amyloid polypeptide, islet amyloid, and diabetes mellitus. Physiological Reviews 201191 795-826. (doi:10.1152/physrev.00042.2009)

12 Jurgens CA, Toukatly MN, Fligner CL, Udayasankar J, Subramanian SL, Zraika S, Aston-Mourney K, Carr DB, Westermark P, Westermark GT, et al. beta-Cell loss and beta-cell apoptosis in human type 2 diabetes are related to islet amyloid deposition. American Journal of Pathology 2011178 2632-2640. (doi:10.1016/j.ajpath.2011.02.036)

13 Udayasankar J, Kodama K, Hull RL, Zraika S, Aston-Mourney K, Subramanian SL, Tong J, Faulenbach MV, Vidal J \& Kahn SE. Amyloid formation results in recurrence of hyperglycaemia following transplantation of human IAPP transgenic mouse islets. Diabetologia 200952 145-153. (doi:10.1007/s00125-008-1185-7)

14 Westermark GT, Westermark P, Nordin A, Tornelius E \& Andersson A. Formation of amyloid in human pancreatic islets transplanted to the liver and spleen of nude mice. Upsala Journal of Medical Sciences 2003 108 193-203. (doi:10.3109/2000-1967-113)

15 Liljeback H, Grapensparr L, Olerud J \& Carlsson PO. Extensive loss of islet mass beyond the first day after intraportal human islet transplantation in a mouse model. Cell Transplantation 201625 481-489. (doi:10.3727/096368915X688902)

16 Zraika S, Hull RL, Udayasankar J, Utzschneider KM, Tong J, Gerchman F \& Kahn SE. Glucose- and time-dependence of islet amyloid formation in vitro. Biochemical and Biophysical Research Communications 2007354 234-239. (doi:10.1016/j.bbrc.2006.12.187)

17 MacArthur DL, de Koning EJ, Verbeek JS, Morris JF \& Clark A. Amyloid fibril formation is progressive and correlates with beta-cell secretion in transgenic mouse isolated islets. Diabetologia 199942 1219-1227. (doi:10.1007/s001250051295)

18 Aston-Mourney K, Hull RL, Zraika S, Udayasankar J, Subramanian SL \& Kahn SE. Exendin-4 increases islet amyloid deposition but offsets the resultant beta cell toxicity in human islet amyloid polypeptide transgenic mouse islets. Diabetologia 201154 1756-1765. (doi:10.1007/s00125-011-2143-3)

19 Verchere CB, D'Alessio DA, Palmiter RD, Weir GC, Bonner-Weir S, Baskin DG \& Kahn SE. Islet amyloid formation associated with hyperglycemia in transgenic mice with pancreatic beta cell expression

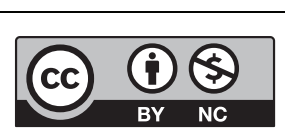

This work is licensed under a Creative Commons Attribution-NonCommercial 4.0 International License. 
of human islet amyloid polypeptide. PNAS 199693 3492-3496. (doi:10.1073/pnas.93.8.3492)

20 Soeller WC, Janson J, Hart SE, Parker JC, Carty MD, Stevenson RW, Kreutter DK \& Butler PC. Islet amyloid-associated diabetes in obese A(vy)/a mice expressing human islet amyloid polypeptide. Diabetes 199847 743-750. (doi:10.2337/diabetes.47.5.743)

21 Hoppener JW, Oosterwijk C, Nieuwenhuis MG, Posthuma G, Thijssen JH, Vroom TM, Ahren B \& Lips CJ. Extensive islet amyloid formation is induced by development of Type II diabetes mellitus and contributes to its progression: pathogenesis of diabetes in a mouse model. Diabetologia 199942 427-434. (doi:10.1007/s001250051175)

22 Paulsson JF \& Westermark GT. Aberrant processing of human proislet amyloid polypeptide results in increased amyloid formation. Diabetes 200554 2117-2125. (doi:10.2337/diabetes.54.7.2117)

23 Ahmad E, Ahmad A, Singh S, Arshad M, Khan AH \& Khan RH. A mechanistic approach for islet amyloid polypeptide aggregation to develop anti-amyloidogenic agents for type-2 diabetes. Biochimie 2011 93 793-805. (doi:10.1016/j.biochi.2010.12.012)

24 Ziolkowski AF, Popp SK, Freeman C, Parish CR \& Simeonovic CJ. Heparan sulfate and heparanase play key roles in mouse beta cell survival and autoimmune diabetes. Journal of Clinical Investigation 2012122 132-141. (doi:10.1172/JCI46177)

25 Young ID, Ailles L, Narindrasorasak S, Tan R \& Kisilevsky R. Localization of the basement membrane heparan sulfate proteoglycan in islet amyloid deposits in type II diabetes mellitus. Archives of Pathology and Laboratory Medicine 1992116 951-954.

26 Park K \& Verchere CB. Identification of a heparin binding domain in the N-terminal cleavage site of pro-islet amyloid polypeptide. Implications for islet amyloid formation. Journal of Biological Chemistry 2001276 16611-16616. (doi:10.1074/jbc.M008423200)

27 Oskarsson ME, Singh K, Wang J, Vlodavsky I, Li JP \& Westermark GT. Heparan sulfate proteoglycans are important for islet amyloid formation and islet amyloid polypeptide-induced apoptosis. Journal of Biological Chemistry 2015290 15121-15132. (doi:10.1074/jbc. M114.631697)

28 Westermark GT, Gebre-Medhin S, Steiner DF \& Westermark P. Islet amyloid development in a mouse strain lacking endogenous islet amyloid polypeptide (IAPP) but expressing human IAPP. Molecular Medicine 20006 998-1007.

29 Andersson A. Isolated mouse pancreatic islets in culture: effects of serum and different culture media on the insulin production of the islets. Diabetologia 197814 397-404. (doi:10.1007/BF01228134)

30 Westermark GT, Johnson KH \& Westermark P. Staining methods for identification of amyloid in tissue. Methods in Enzymology 1999309 3-25. (doi:10.1016/s0076-6879(99)09003-5)

31 Sandler S, Andersson A \& Hellerstrom C. Inhibitory effects of interleukin 1 on insulin secretion, insulin biosynthesis, and oxidative metabolism of isolated rat pancreatic islets. Endocrinology 1987121 1424-1431. (doi:10.1210/endo-121-4-1424)

32 Scott JE \& Dorling J. Differential staining of acid glycosaminoglycans (mucopolysaccharides) by alcian blue in salt solutions. Histochemie 19655 221-233. (doi:10.1007/BF00306130)

33 Aslund A, Sigurdson CJ, Klingstedt T, Grathwohl S, Bolmont T, Dickstein DL, Glimsdal E, Prokop S, Lindgren M, Konradsson P, et al. Novel pentameric thiophene derivatives for in vitro and in vivo optical imaging of a plethora of protein aggregates in cerebral amyloidoses. ACS Chemical Biology 20094 673-684. (doi:10.1021/ cb900112v)

34 Schultz SW, Nilsson KP \& Westermark GT. Drosophila melanogaster as a model system for studies of islet amyloid polypeptide aggregation. PLOS ONE 20116 e20221. (doi:10.1371/journal.pone.0020221)

35 Marzban L, Rhodes CJ, Steiner DF, Haataja L, Halban PA \& Verchere $\mathrm{CB}$. Impaired NH2-terminal processing of human proislet amyloid polypeptide by the prohormone convertase PC2 leads to amyloid formation and cell death. Diabetes 200655 2192-2201. (doi:10.2337/ db05-1566)
36 Jansson L, Barbu A, Bodin B, Drott CJ, Espes D, Gao X, Grapensparr L, Kallskog O, Lau J, Liljeback H, et al. Pancreatic islet blood flow and its measurement. Upsala Journal of Medical Sciences 2016121 81-95. (doi:10.3109/03009734.2016.1164769)

37 Prinzen FW \& Bassingthwaighte JB. Blood flow distributions by microsphere deposition methods. Cardiovascular Research 200045 13-21. (doi:10.1016/S0008-6363(99)00252-7)

38 Eizirik DL, Cardozo AK \& Cnop M. The role for endoplasmic reticulum stress in diabetes mellitus. Endocrine Reviews 200829 42-61. (doi:10.1210/er.2007-0015)

39 Hull RL, Zraika S, Udayasankar J, Aston-Mourney K, Subramanian SL \& Kahn SE. Amyloid formation in human IAPP transgenic mouse islets and pancreas, and human pancreas, is not associated with endoplasmic reticulum stress. Diabetologia 200952 1102-1111. (doi:10.1007/s00125-009-1329-4)

40 Borromeo CM, Pottier X, In't Veld PA, Pipeleers-Marichal MA, Kaufman L, Pipeleers DG \& Van Schravendijk CF. Heterogeneity in distribution of amyloid-positive islets in type-2 diabetic patients. Virchows Archiv 2005446 232-238. (doi:10.1007/s00428-004-1171-5)

41 Wang J, Xu J, Finnerty J, Furuta M, Steiner DF \& Verchere CB. The prohormone convertase enzyme 2 (PC2) is essential for processing pro-islet amyloid polypeptide at the NH2-terminal cleavage site. Diabetes 200150 534-539. (doi:10.2337/diabetes.50.3.534)

42 Andersson A, Bohman S, Borg LA, Paulsson JF, Schultz SW, Westermark GT \& Westermark P. Amyloid deposition in transplanted human pancreatic islets: a conceivable cause of their longterm failure. Experimental Diabetes Research 20082008562985. (doi:10.1155/2008/562985)

43 Paulsson JF, Andersson A, Westermark P \& Westermark GT. Intracellular amyloid-like deposits contain unprocessed pro-islet amyloid polypeptide (proIAPP) in beta cells of transgenic mice overexpressing the gene for human IAPP and transplanted human islets. Diabetologia 200649 1237-1246. (doi:10.1007/s00125-0060206-7)

44 Westermark P, Engstrom U, Westermark GT, Johnson KH, Permerth J $\&$ Betsholtz C. Islet amyloid polypeptide (IAPP) and pro-IAPP immunoreactivity in human islets of Langerhans. Diabetes Research and Clinical Practice 19897 219-226. (doi:10.1016/01688227(89)90008-9)

45 Kahn SE \& Halban PA. Release of incompletely processed proinsulin is the cause of the disproportionate proinsulinemia of NIDDM. Diabetes 199746 1725-1732. (doi:10.2337/diab.46.11.1725)

46 Alarcon C, Verchere CB \& Rhodes CJ. Translational control of glucoseinduced islet amyloid polypeptide production in pancreatic islets. Endocrinology 2012153 2082-2087. (doi:10.1210/en.2011-2019)

47 Alarcon C, Lincoln B \& Rhodes CJ. The biosynthesis of the subtilisinrelated proprotein convertase PC3, but no that of the PC2 convertase, is regulated by glucose in parallel to proinsulin biosynthesis in rat pancreatic islets. Journal of Biological Chemistry 1993268 4276-4280.

48 Fricker LD, McKinzie AA, Sun J, Curran E, Qian Y, Yan L, Patterson $\mathrm{SD}$, Courchesne PL, Richards B, Levin N, et al. Identification and characterization of proSAAS, a granin-like neuroendocrine peptide precursor that inhibits prohormone processing. Journal of Neuroscience 200020 639-648.

49 Marzban L, Trigo-Gonzalez G, Zhu X, Rhodes CJ, Halban PA, Steiner DF \& Verchere CB. Role of beta-cell prohormone convertase (PC) $1 / 3$ in processing of pro-islet amyloid polypeptide. Diabetes $2004 \mathbf{5 3}$ 141-148. (doi:10.2337/diabetes.53.1.141)

50 Zhu X, Orci L, Carroll R, Norrbom C, Ravazzola M \& Steiner DF. Severe block in processing of proinsulin to insulin accompanied by elevation of des-64,65 proinsulin intermediates in islets of mice lacking prohormone convertase 1/3. PNAS 200299 10299-10304. (doi:10.1073/pnas.162352799)

51 Courtade JA, Wang EY, Yen P, Dai DL, Soukhatcheva G, Orban PC \& Verchere CB. Loss of prohormone convertase 2 promotes beta cell dysfunction in a rodent transplant model expressing human pro-islet

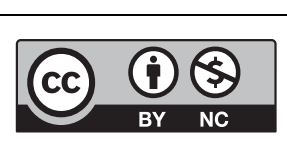

This work is licensed under a Creative Commons Attribution-NonCommercial 4.0 International License. 
amyloid polypeptide. Diabetologia 201760 453-463. (doi:10.1007/ s00125-016-4174-2)

52 Meng F, Abedini A, Song B \& Raleigh DP. Amyloid formation by pro-islet amyloid polypeptide processing intermediates: examination of the role of protein heparan sulfate interactions and implications for islet amyloid formation in type 2 diabetes. Biochemistry $2007 \mathbf{4 6}$ 12091-12099. (doi:10.1021/bi7004834)

53 Lee JM, Yin KJ, Hsin I, Chen S, Fryer JD, Holtzman DM, Hsu CY \& $\mathrm{Xu}$ J. Matrix metalloproteinase-9 and spontaneous hemorrhage in an animal model of cerebral amyloid angiopathy. Annals of Neurology 200354 379-382. (doi:10.1002/ana.10671)

54 Hernandez-Guillamon M, Mawhirt S, Blais S, Montaner J, Neubert TA, Rostagno A \& Ghiso J. Sequential amyloid-beta degradation by the matrix metalloproteases MMP-2 and MMP-9. Journal of Biological Chemistry 2015290 15078-15091. (doi:10.1074/jbc. M114.610931)

55 Aston-Mourney K, Zraika S, Udayasankar J, Subramanian SL, Green PS, Kahn SE \& Hull RL. Matrix metalloproteinase-9 reduces islet amyloid formation by degrading islet amyloid polypeptide. Journal of Biological Chemistry 2013288 3553-3559. (doi:10.1074/jbc. M112.438457)

56 Christoffersson G, Walden T, Sandberg M, Opdenakker G, Carlsson $\mathrm{PO} \&$ Phillipson M. Matrix metalloproteinase-9 is essential for physiological Beta cell function and islet vascularization in adult mice. American Journal of Pathology 2015185 1094-1103. (doi:10.1016/j.ajpath.2014.12.009)

Received in final form 13 July 2017

Accepted 8 August 2017

Accepted Preprint published online 8 August 2017 http://www.endocrineconnections.org DOI: 10.1530/EC-17-0148
(C) 2017 The authors Published by Bioscientifica Ltd

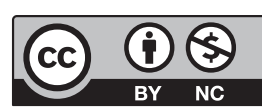

This work is licensed under a Creative Commons Attribution-NonCommercial 4.0 International License. 